\title{
Karakterisasi Senyawa Metabolit pada Kultur Anggrek Dendrobium anosmum-gigantea
}

\author{
Alfian Hendra Krisnawan, Sajekti Palupi, Ni Made Swasti Wandhini, Sitti Suhartina, Alrivani \\ Eka Yuli Saputri, I Gusti Agung Made Shinta Ari Putri dan Oeke Yunita
}

Departemen Biologi Farmasi, Fakultas Farmasi, Universitas Surabaya, Surabaya, Indonesia

Korespondensi: Alfian Hendra Krisnawan

Email: alfian_hendra_k@staff.ubaya.ac.id

Submitted : 25-11-2019, Revised : 06-03-2020, Accepted : 30-05-2020

\begin{abstract}
ABSTRAK: Dendrobium sp. adalah salah satu spesies anggrek yang dapat dimanfaatkan sebagai tanaman obat karena menghasilkan berbagai macam metabolit penting, diantaranya adalah alkaloid yang berfungsi sebagai antioksidan, antikanker, dan mempunyai aktivitas neuroprotektif. Tujuan penelitian ini adalah untuk mengetahui senyawa metabolit yang dihasilkan dari kultur pucuk Dendrobium anosmum-gigantea, yang dibandingkan dengan tanaman induk menggunakan skrining fitokimia, kromatografi, dan densitometri. Kultur pucuk dilakukan menggunakan media MS dengan ZPT NAA 0,5 ppm dan BAP 0,5 ppm. Ekstraksi kultur pucuk dan tanaman induk dilakukan dengan metode ultrasonikasi. Skrining fitokimia dilakukan menggunakan metode spot test dan Kromatografi Lapis Tipis (KLT). Hasil skrining fitokimia menunjukkan bahwa ada 4 golongan senyawa yang sama-sama dihasilkan oleh ekstrak kultur pucuk dan tanaman induk yaitu alkaloid, flavonoid, tannin, dan fenol. Analisis kandungan alkaloid antara kultur pucuk dan tanaman induk dengan metode KLT menggunakan fase gerak kloroform : metanol (12:2) menghasilkan 2 noda pada Rf 0,41-0,43 dan 0,75-0,78. Sementara itu, dengan metode densitometri menunjukkan spektra densitogram yang muncul pada Rf 0,50-0,60 dan 0,90-1,00. Kesimpulannya, kultur pucuk Dendrobium anosmumgigantea mempunyai kemiripan kandungan golongan senyawa dengan tanaman induk jika dilihat dari hasil skrining fitokimia, kromatografi, dan densitometri, sehingga kultur pucuk bisa digunakan sebagai alternatif untuk produksi golongan senyawa yang sama pada tanaman anggrek Dendrobium anosmum-gigantea.
\end{abstract}

Kata kunci: dendrobium; kultur pucuk; alkaloid; skrining fitokimia

ABSTRACT: Dendrobium sp. is one of the orchid species that was used as a medicinal plant and produces a variety of important metabolites such as alkaloids having antioxidant, anticancer, and neuroprotective activity. This research was aimed to analyze the composition of metabolites produced from shoot culture of Dendrobium anosmum-gigantea compared with related parent plants using phytochemical screening, chromatographic, and densitometric methods. Shoot cultures were performed using MS medium with 0.5 ppm NAA and 0.5 ppm BAP. The extraction of shoot cultures and parent plants was carried out by ultrasonication. Phytochemical screening was conducted using the spot test method and Thin Layer Chromatography (TLC). The results showed that the shoot cultures and parent plant extracts contain four chemical compound groups, i.e. alkaloids, flavonoids, tannins, and phenols. Alkaloid analysis on shoot cultures and parent plants by TLC method using the mobile phase of chloroform : methanol (12:2) showed two spots at the Rf value of 0.41-0.43 and 0.75-0.78. Densitogram showed two peaks at the Rf value of 0.50-0.60 and 0.90-1.00. In conclusion, shoot culture of Dendrobium anosmum-gigantea and its parent plant showed similar compounds, therefore shoot culture can be used as an alternative for the Dendrobium anosmum-gigantea parent plant.

Keywords: dendrobium; shoot culture; alkaloids; phytochemical screening 


\section{Pendahuluan}

Anggrek merupakan tanaman hias dengan keindahan bunganya dan memiliki nilai jual yang tinggi. Namun di balik keindahan tersebut, anggrek mempunyai manfaat antara lain sebagai produk herbal dan bahan kosmetika. Salah satu spesies anggrek yang dapat dimanfaatkan sebagai tanaman obat adalah anggrek Dendrobium sp. [1]. Potensi Dendrobium sp. sebagai obat dikarenakan anggrek ini menghasilkan berbagai macam metabolit penting, salah satunya adalah alkaloid. Alkaloid utama pada Dendrobium sp. adalah Dendrobine $\left(\mathrm{C}_{16} \mathrm{H}_{25} \mathrm{O}_{2} \mathrm{~N}\right)[2]$.

Senyawa alkaloid pada Dendrobium crumetanum $s w$ berpotensi untuk pengobatan radang telinga bagian dalam [3]. Daun anggrek Dendrobium auranticum dapat digunakan sebagai obat hipotensi, sedangkan daun Dendrobium chrysantum dan Dendrobium densiflorum dapat digunakan sebagai obat diabetes [1], serta ada beberapa spesies Dendrobium yang mempunyai aktivitas antibakteri [4]. Alkaloid pada spesies Dendrobium dapat berfungsi sebagai antioksidan, antikanker, dan mempunyai aktivitas neuroprotektif [5]. Permasalahan yang sering ditemukan pada produk herbal adalah kondisi lingkungan dan perbedaan letak geografis yang dapat mempengaruhi produksi metabolit sekunder, bahkan juga untuk produk yang dihasilkan oleh spesies tanaman yang sama [6]. Permasalahan tersebut dapat diatasi dengan perbanyakan tanaman menggunakan kultur jaringan tanaman [7].

Penelitian sebelumnya yang dilakukan pada anggrek Dendrobium anosmum-gigantea, yaitu kultur pucuk menggunakan media MS dengan penambahan zat pengatur tumbuh Naftalen Asam Asetat (NAA) dan Benzyl Amino Purine (BAP) menghasilkan kultur pucuk optimum pada konsentrasi NAA 0,5 ppm dan BAP 0,5 ppm [8]. Penelitian lain menemukan bahwa terdapat dua senyawa alkaloid pada kultur biji Dendronium huoshanense menggunakan HPLC dan TLC, sedangkan tanaman anggrek utuh untuk spesies yang sama mengandung empat senyawa alkaloid
[9]. Tujuan dari penelitian ini adalah melakukan karakterisasi senyawa metabolit yang dihasilkan dari kultur pucuk Dendrobium anosmum-gigantea yang dibandingkan dengan tanaman induknya yang utuh, menggunakan analisis skrining fitokimia, kromatografi, dan densitometri. Gambar tanaman Dendrobium anosmum-gigantea dapat dilihat pada Gambar 1. Penelitian ini merupakan tahap dasar dalam teknologi bioproses senyawa metabolit sekunder pada sistem kultur jaringan tanaman yang dapat diaplikasikan pada industri obat herbal.

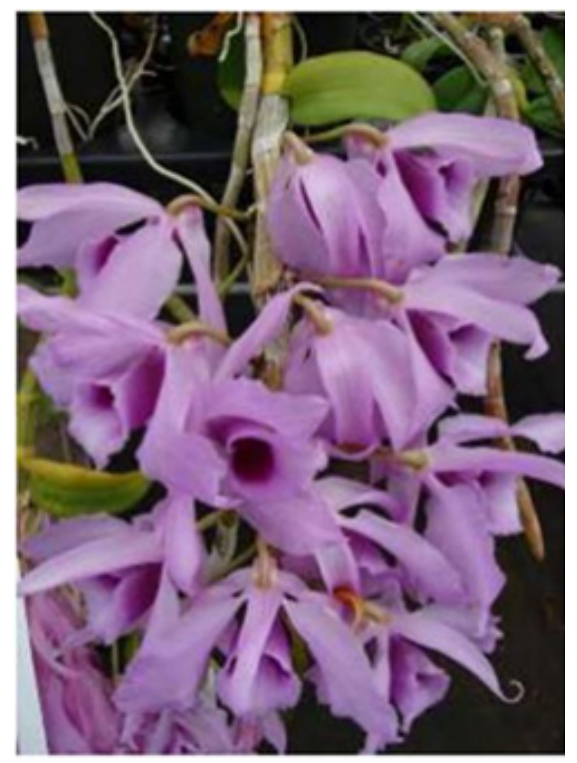

Gambar 1. Tanaman Dendrobium anosmum-gigantea [10]

\section{Metode}

\subsection{Subkultur pucuk Dendrobium anosmum- gigantea}

Kultur pucuk steril Dendrobium anosmum-gigantea yang dikembangkan di Fakultas Farmasi Universitas Surabaya disubkultur pada media MS (Murashige dan Skoog) dengan tambahan ZPT Naftalen Asam Asetat (NAA) 0,5 ppm dan Benzyl Amino Purine (BAP) 0,5 ppm. Media MS yang digunakan mengandung $30 \mathrm{~g} / \mathrm{L}(3 \%)$ sukrosa dan 0,8 \% Agar. pH media disesuaikan pada nilai 5,8 menggunakan $1 \mathrm{~N} \mathrm{HCl}$ atau $1 \mathrm{~N} \mathrm{NaOH}$ sebelum disterilisasi. Media disterilisasi dengan menggunakan autoklaf pada suhu $121^{\circ} \mathrm{C}$ selama 15 menit.

Kultur pucuk diinkubasi pada suhu ruang 
$27 \pm 2^{\circ} \mathrm{C}$ dan kelembaban $80 \%$ di bawah lampu white fluorescent dengan intensitas 2000 lux. Setelah 25 hari, hasil kultur dievaluasi panjang dan jumlah dari pucuk yang terbentuk untuk nantinya dipersiapkan untuk diekstraksi. Hasil tunas yang baik, yaitu berwarna hijau, bertambah panjang, jumlah dan massanya, diambil dari media kultur dan dicuci menggunakan aquades untuk menghilangkan sisa Agar dari media.

\subsection{Ekstraksi}

Pucuk hasil kultur dan tanaman induk masingmasing dipotong kecil, kemudian ditimbang sebanyak $500 \mathrm{mg}$ dan digerus dalam kondisi dingin dengan mortir dan stamper hingga halus. Pucuk yang sudah halus dimasukkan ke dalam tabung sentrifus dan ditambahkan $5 \mathrm{ml}$ etanol 70\%. Campuran tersebut dihomogenkan dengan vortex selama 1 menit, kemudian diekstraksi berulang sebanyak 5 kali dengan cara ultrasonikasi yang dibagi menjadi 2 tahap, yaitu 2 x 10 menit dan tahap kedua 3 x 5 menit. Tahap pertama disonikasi selama 10 menit, kemudian dipisahkan filtrat dan residu dengan cara disentrifugasi dengan kecepatan 3000 rpm selama 1 menit, disaring menggunakan kertas saring. Residu hasil pemisahan disonikasi kembali selama 10 menit dan dipisahkan kembali filtrat dan residunya. Tahap kedua dilakukan hal yang sama dengan tahap pertama sebanyak 3 kali dengan waktu masing-masing 5 menit. Selanjutnya, filtrat hasil pemisahan dimasukkan ke dalam labu ukur $25 \mathrm{ml}$ dan ditambahkan etanol 70\% sampai $25 \mathrm{ml}$ (adaptasi dari Yunita, 2011) [6].

\subsection{Analisis fitokimia}

Ekstrak dari kultur pucuk dan tanaman induk masing-masing diuji kualitatif untuk mengetahui kandungan aktif seperti alkaloid, flavonoid, steroid, terpenoid, saponin, tanin, dan fenol, melalui prosedur standar skrining fitokimia menggunakan reagen dan reaksi warna. Pengujian senyawa alkaloid dapat dilakukan menggunakan pereaksi Dragendorf. Terbentuknya endapan merah menunjukkan adanya senyawa alkaloid. Selain itu, analisa alkaloid juga dapat menggunakan pereaksi Mayer dan Wagner dengan hasil positif jika menunjukkan adanya endapan putih (Mayer) dan endapan coklat (Wagner). Pengujian senyawa flavonoid menggunakan serbuk $\mathrm{Mg}$ dan $\mathrm{HCl}$ pekat dengan terbentuknya warna merah/kuning/ jingga. Pengujian senyawa steroid dan terpenoid menggunakan $\mathrm{CH}_{3} \mathrm{COOH}$ glasial dan $\mathrm{H}_{2} \mathrm{SO}_{4}$ dengan terbentuknya warna ungu/jingga/kuning keemasan untuk triterpenoid dan warna biru atau hijau untuk steroid. Pengujian senyawa saponin menggunakan $\mathrm{HCl} 1 \mathrm{~N}$ dengan terbentuknya busa stabil. Pengujian senyawa tanin dan fenol menggunakan $\mathrm{FeCl}_{3}$ dengan terbentuknya warna biru hitam atau coklat hitam.

\subsection{Analisis kromatografi}

Ekstrak kultur pucuk dan tanaman induk masing-masing dianalisis dengan menggunakan metode kromatografi lapis tipis (KLT) untuk mengetahui kandungan metabolit yang terdapat dalam ekstrak etanol. Fase gerak yang digunakan untuk mengeluasi sampel dibuat variasi berdasarkan gradien kepolaran. Pereaksi penampak noda disesuaikan dengan metabolit sekunder yang diamati. Untuk alkaloid total telah dioptimasi fase geraknya menggunakan 3 komposisi fase gerak yang berbeda yaitu kloroform : metanol : amonia (85:15:1), etil asetat : kloroform (8:2), kloroform : metanol (12:2) dan menggunakan fase diam plat silica gel GF 254 .

\subsection{Analisis densitometri}

Ekstrak tanaman induk dan kultur pucuk masing-masing dianalisis dengan Densitometer (Camag TLC Scanner 4). Sebelum dilakukan pengamatan profil metabolit, dilakukan scanning terlebih dahulu untuk menentukan panjang gelombang maksimum dari ekstrak pucuk. Spektrum yang terbentuk dianalisa berdasarkan puncak dan area yang terbentuk pada panjang gelombang tertentu kemudian dibandingkan 
profil spektrum yang dihasilkan oleh ekstrak tanaman induk dan kultur pucuk Dendrobium anosmum-gigantea.

\section{Hasil dan diskusi}

\subsection{Persiapan sampel}

Hasil subkultur pucuk Dendrobium anosmumgigantea menggunakan media MS dengan konsentrasi ZPT NAA 0,5 ppm dan BAP 0,5 ppm. Keberhasilan subkultur dilihat melalui peningkatan Indeks Pertumbuhan (IP) pucuk. Hasil IP yang terukur adalah 1,058 \pm 0,0151. Pemilihan kultur pucuk dan tanaman induk anggrek Dendrobium anosmum-gigantea untuk diekstraksi adalah pucuk berwarna hijau, yang menandakan bahwa kondisi tanaman sampel baik [11]. Penimbangan pucuk menghasilkan rata-rata 215,3 $\pm 1,07 \mathrm{mg}$, sedangkan tanaman induk ratarata penimbangannya $220,5 \pm 9,87 \mathrm{mg}$. Ekstraksi dilakukan dengan metode ultrasonikasi dalam etanol $70 \%$ dan dilakukan ekstraksi berulang sebanyak 5 kali untuk mendapatkan ekstrak yang maksimal [6].
Kedua ekstrak memiliki kriteria jernih dan berwarna hijau, tetapi intensitas warnanya lebih pekat terlihat pada ekstrak dari tanaman induk jika dibandingkan dengan ekstrak yang berasal dari kultur pucuk. Intensitas warna hijau pada ekstrak ditimbulkan oleh metabolit yang terkandung dalam tanaman, khususnya adalah kandungan klorofil, sehingga kemungkinan intensitas warna ekstrak tanaman induk lebih tinggi dibanding kultur pucuk karena kandungan klorofil tanaman induk lebih banyak. Klorofil merupakan metabolit utama yang menyebabkan warna hijau pada tanaman khususnya pada daun [11]. Metabolit yang dihasilkan tanaman induk umumnya lebih banyak dari pada tanaman yang dikultur, karena media kultur yang digunakan baru dan tanaman perlu adaptasi untuk sama seperti tanaman induknya $[12,13]$. Hasil ekstraksi dapat dilihat pada Gambar 2.

\subsection{Skrining fitokimia}

Kandungan golongan senyawa ekstrak dianalisis dengan menggunakan metode skrining fitokimia menggunakan spot test dan metode KLT.
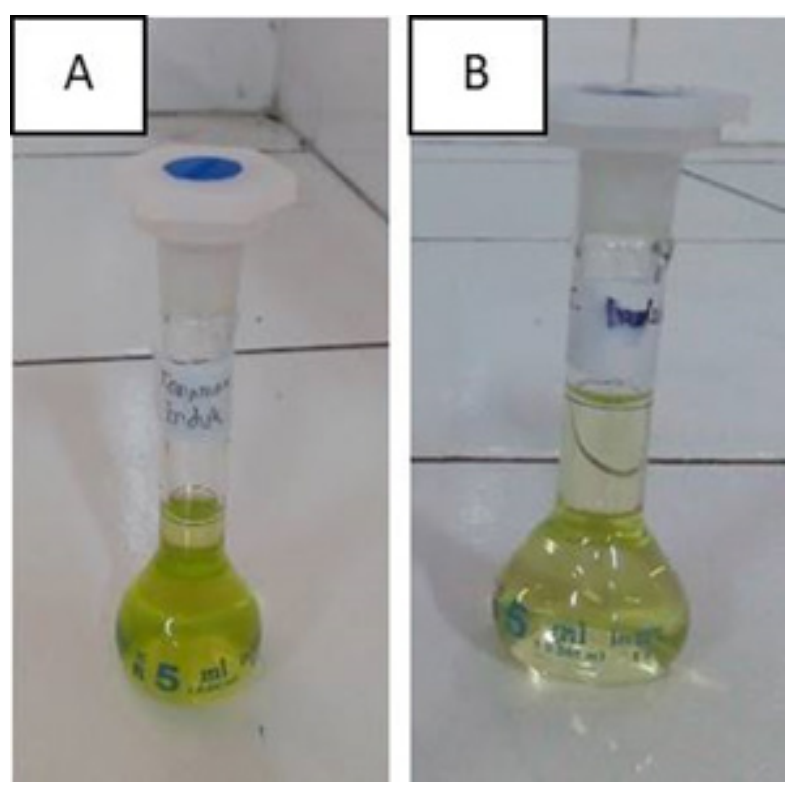

Gambar 2. Hasil ekstraksi tanaman induk (A) dan kultur pucuk (B)

Hasil skrining fitokimia spot test tanaman induk dan kultur pucuk Dendrobium anosmum-gigantea dapat dilihat pada Tabel 1, sedangkan hasil KLT pada Tabel 2 dan Tabel 3.
Dari hasil skrining fitokimia yang dilakukan menggunakan metode spot test dan KLT, kedua ekstrak baik dari tanaman induk maupun kultur pucuk mengandung golongan senyawa yang 
Tabel 1. Hasil skrining fitokimia spot test

\begin{tabular}{|c|c|c|c|c|}
\hline \multirow[t]{2}{*}{ Golongan senyawa } & \multicolumn{2}{|c|}{ Tanaman induk } & \multicolumn{2}{|l|}{ Kultur pucuk } \\
\hline & $\begin{array}{l}\text { Keberadaan } \\
\text { senyawa }\end{array}$ & Hasil & $\begin{array}{l}\text { Keberadaan se- } \\
\text { nyawa }\end{array}$ & Hasil \\
\hline \multirow[t]{3}{*}{ Alkaloid } & + & $\begin{array}{l}\text { Endapan putih } \\
\text { (Mayer) }\end{array}$ & + & Endapan putih (Mayer) \\
\hline & + & $\begin{array}{l}\text { Endapan } \\
\text { merah bata } \\
\text { (Dragendorf) }\end{array}$ & + & $\begin{array}{l}\text { Endapan merah bata } \\
\text { (Dragendorf) }\end{array}$ \\
\hline & + & $\begin{array}{l}\text { Endapan } \\
\text { coklat (Wag- } \\
\text { ner) }\end{array}$ & + & $\begin{array}{l}\text { Endapan coklat (Wag- } \\
\text { ner) }\end{array}$ \\
\hline Flavonoid & - & $\begin{array}{l}\text { Tidak ada pe- } \\
\text { rubahan }\end{array}$ & - & Tidak ada perubahan \\
\hline Steroid dan terpenoid & - & $\begin{array}{l}\text { Tidak ada pe- } \\
\text { rubahan }\end{array}$ & - & Tidak ada perubahan \\
\hline Saponin & - & $\begin{array}{l}\text { Tidak terben- } \\
\text { tuk busa }\end{array}$ & - & Tidak terbentuk busa \\
\hline Tanin & + & $\begin{array}{l}\text { Terbentuk } \\
\text { warna coklat } \\
\text { kehitaman }\end{array}$ & + & $\begin{array}{l}\text { Terbentuk warna } \\
\text { coklat kehitaman }\end{array}$ \\
\hline Fenol & + & $\begin{array}{l}\text { Terbentuk } \\
\text { warna coklat } \\
\text { kehitaman }\end{array}$ & + & $\begin{array}{l}\text { Terbentuk warna } \\
\text { coklat kehitaman }\end{array}$ \\
\hline
\end{tabular}

Keterangan:

$(+)=$ kemungkinan adanya golongan senyawa

$(-)=$ tidak adanya golongan senyawa

Tabel 2. Hasil skrining fitokimia metode KLT tanaman induk

\begin{tabular}{|c|c|c|c|c|c|c|c|}
\hline \multirow{2}{*}{$\begin{array}{l}\text { Golongan } \\
\text { senyawa }\end{array}$} & \multirow{2}{*}{$\begin{array}{l}\text { Sinar tam- } \\
\text { pak }\end{array}$} & \multicolumn{2}{|l|}{ UV } & \multirow[t]{2}{*}{$R f$} & \multirow{2}{*}{$\begin{array}{l}\text { Pereaksi } \\
\text { penampak } \\
\text { noda }\end{array}$} & \multirow{2}{*}{$\begin{array}{l}\text { Warna } \\
\text { noda }\end{array}$} & \multirow{2}{*}{$\begin{array}{l}\text { Keberadaan } \\
\text { senyawa }\end{array}$} \\
\hline & & $254 \mathrm{~nm}$ & $366 \mathrm{~nm}$ & & & & \\
\hline Alkaloid & $\begin{array}{l}\text { Hijau } \\
\text { muda }\end{array}$ & Hijau & $\begin{array}{l}\text { Fluoresensi } \\
\text { jingga }\end{array}$ & $\begin{array}{l}0,42 \\
0,85\end{array}$ & Dragendorf & Coklat & + \\
\hline Flavonoid & $\begin{array}{l}\text { Kuning ke- } \\
\text { hijauan }\end{array}$ & Kuning & $\begin{array}{l}\text { Fluoresensi } \\
\text { jingga }\end{array}$ & $\begin{array}{l}0,65 \\
0,75\end{array}$ & Uap amonia & $\begin{array}{l}\text { Kuning } \\
\text { (sesaat } \\
\text { setelah di- } \\
\text { uapkan) }\end{array}$ & + \\
\hline $\begin{array}{l}\text { Steroid dan } \\
\text { terpenoid }\end{array}$ & $\begin{array}{l}\text { Jingga ke- } \\
\text { hijauan }\end{array}$ & $\begin{array}{l}\text { Merah muda } \\
\text { keunguan }\end{array}$ & $\begin{array}{l}\text { Fluoresensi } \\
\text { jingga }\end{array}$ & 0,2 & $\begin{array}{l}\text { Lieberman- } \\
\text { Burchard }\end{array}$ & $\begin{array}{l}\text { Jingga kehi- } \\
\text { jauan }\end{array}$ & - \\
\hline Saponin & $\begin{array}{l}\text { Hijau ke- } \\
\text { coklatan }\end{array}$ & $\begin{array}{l}\text { Kuning ke- } \\
\text { coklatan }\end{array}$ & $\begin{array}{l}\text { Fluoresensi } \\
\text { jingga }\end{array}$ & $\begin{array}{l}0,17 \\
0,59 \\
0,74\end{array}$ & $\begin{array}{l}\text { Lieberman- } \\
\text { Burchard }\end{array}$ & $\begin{array}{l}\text { Hijau ke- } \\
\text { coklatan }\end{array}$ & - \\
\hline Tanin & $\begin{array}{l}\text { Jingga ke- } \\
\text { hijauan }\end{array}$ & Merah muda & $\begin{array}{l}\text { Fluoresensi } \\
\text { biru keabuan }\end{array}$ & 0,76 & $\mathrm{FeCl}_{3}$ & $\begin{array}{l}\text { Abu-abu } \\
\text { kecoklatan }\end{array}$ & + \\
\hline Fenol & $\begin{array}{l}\text { Hijau } \\
\text { muda }\end{array}$ & Hijau & $\begin{array}{l}\text { Fluoresensi } \\
\text { jingga }\end{array}$ & 0,12 & $\begin{array}{l}\text { Folin Ciocal- } \\
\text { teau }\end{array}$ & Biru muda & + \\
\hline
\end{tabular}

Keterangan:

$(+)=$ kemungkinan adanya golongan senyawa

$(-)$ = tidak adanya golongan senyawa 
Tabel 3. Hasil skrining fitokimia metode KLT kultur pucuk

\begin{tabular}{|c|c|c|c|c|c|c|c|}
\hline \multirow{2}{*}{$\begin{array}{l}\text { Golongan } \\
\text { senyawa }\end{array}$} & \multirow{2}{*}{$\begin{array}{l}\text { Sinar tam- } \\
\text { pak }\end{array}$} & \multicolumn{2}{|l|}{ UV } & \multirow[t]{2}{*}{$R f$} & \multirow{2}{*}{$\begin{array}{l}\text { Pereaksi } \\
\text { penampak } \\
\text { noda }\end{array}$} & \multirow{2}{*}{$\begin{array}{l}\text { Warna } \\
\text { noda }\end{array}$} & \multirow{2}{*}{$\begin{array}{l}\text { Keberadaan } \\
\text { senyawa }\end{array}$} \\
\hline & & $254 \mathrm{~nm}$ & $366 \mathrm{~nm}$ & & & & \\
\hline Alkaloid & $\begin{array}{l}\text { Hijau } \\
\text { muda }\end{array}$ & Hijau & $\begin{array}{l}\text { Fluoresensi } \\
\text { jingga }\end{array}$ & $\begin{array}{l}0,4 \\
0,83\end{array}$ & Dragendorf & Coklat & + \\
\hline Flavonoid & $\begin{array}{l}\text { Kuning ke- } \\
\text { hijauan }\end{array}$ & Kuning & $\begin{array}{l}\text { Fluoresensi } \\
\text { jingga }\end{array}$ & $\begin{array}{l}0,64 \\
0,74\end{array}$ & Uap amonia & $\begin{array}{l}\text { Kuning } \\
\text { (sesaat } \\
\text { setelah di- } \\
\text { uapkan) }\end{array}$ & + \\
\hline $\begin{array}{l}\text { Steroid dan } \\
\text { terpenoid }\end{array}$ & $\begin{array}{l}\text { Jingga ke- } \\
\text { hijauan }\end{array}$ & $\begin{array}{l}\text { Merah muda } \\
\text { keunguan }\end{array}$ & $\begin{array}{l}\text { Fluoresensi } \\
\text { jingga }\end{array}$ & 0,21 & $\begin{array}{l}\text { Lieberman- } \\
\text { Burchard }\end{array}$ & $\begin{array}{l}\text { Jingga kehi- } \\
\text { jauan }\end{array}$ & - \\
\hline Saponin & $\begin{array}{l}\text { Hijau ke- } \\
\text { coklatan }\end{array}$ & $\begin{array}{l}\text { Kuning ke- } \\
\text { coklatan }\end{array}$ & $\begin{array}{l}\text { Fluoresensi } \\
\text { jingga }\end{array}$ & $\begin{array}{l}0,21 \\
0,65 \\
0,81\end{array}$ & $\begin{array}{l}\text { Lieberman- } \\
\text { Burchard }\end{array}$ & $\begin{array}{l}\text { Hijau ke- } \\
\text { coklatan }\end{array}$ & - \\
\hline Tanin & $\begin{array}{l}\text { Jingga ke- } \\
\text { hijauan }\end{array}$ & Merah muda & $\begin{array}{l}\text { Fluoresensi } \\
\text { biru }\end{array}$ & 0,71 & $\mathrm{FeCl}_{3}$ & $\begin{array}{l}\text { Abu-abu } \\
\text { kecoklatan }\end{array}$ & + \\
\hline Fenol & $\begin{array}{l}\text { Hijau } \\
\text { muda }\end{array}$ & Hijau & $\begin{array}{l}\text { Fluoresensi } \\
\text { jingga }\end{array}$ & 0,11 & $\begin{array}{l}\text { Folin Ciocal- } \\
\text { teau }\end{array}$ & Biru muda & + \\
\hline
\end{tabular}

Keterangan:

$(+)=$ kemungkinan adanya golongan senyawa

$(-)=$ tidak adanya golongan senyawa

sama, yaitu alkaloid, flavonoid, tannin, dan fenol. Alkaloid pada spesies Dendrobium, salah satunya senyawa dendrobine mempunyai aktivitas farmakologi seperti anti kanker [14], antivirus [15], sehingga dilakukan identifikasi senyawa alkaloid untuk mengidentifikasi kemiripan antara kultur pucuk dan tanaman induk.

Optimasi fase gerak dilakukan untuk identifikasi golongan senyawa alkaloid pada tanaman induk. Tiga jenis fase gerak yang dipakai yaitu kloroform : metanol : amonia (85:15:1), etil asetat : kloroform (8:2), kloroform : metanol (12:2). Fase gerak terbaik untuk senyawa alkaloid yang diperoleh adalah kloroform : metanol (12:2) dengan menghasilkan pemisahan yang baik yaitu 2 noda warna coklat pada Rf 0,42 dan 0,83 (menggunakan penampak noda Dragendorf).

\subsection{Analisis kromatografi}

Fase gerak kloroform : metanol (12:2) digunakan untuk mengeluasi ekstrak tanaman induk dan kultur pucuk Dendrobium anosmumgigantea. Hasil eluasi diamati pada sinar tampak, UV $254 \mathrm{~nm}, 366 \mathrm{~nm}$, dan pemberian penampak noda Dragendorf. Hasil identifikasi alkaloid dengan KLT dapat dilihat pada Tabel 4 dan

Tabel 4. Hasil identifikasi senyawa alkaloid pada tanaman induk dan kultur pucuk Dendrobium anosmum-gigantea

\begin{tabular}{lll}
\hline Parameter & Tanaman induk & Kultur pucuk \\
\hline Jumlah noda & 2 & 2 \\
Sinar tampak & Hijau muda & Hijau muda \\
UV $254 \mathrm{~nm}$ & Hijau & Hijau \\
UV $366 \mathrm{~nm}$ & Fluorosensi jingga & Fluorosensi jingga \\
Rf & $0,43-0,78$ & $0,41-0,75$ \\
Dragendorf & Coklat & Coklat \\
Keberadaan senyawa alkaloid & ++ & ++ \\
\hline
\end{tabular}




\section{Gambar 3.}

Noda yang dihasilkan oleh ekstrak tanaman induk dan kultur pucuk menunjukkan hasil yang sama, yaitu menghasilkan 2 noda pada Rf 0,410,43 dan 0,75-0,78, sehingga dapat disimpulkan bahwa ada kemiripan kandungan golongan senyawa, dengan intensitas warna noda pada tanaman induk lebih tinggi, yang diasumsikan karena konsentrasi senyawa yang lebih tinggi pada tanaman induk.

\subsection{Analisis densitometri}

Analisis secara densitometri dilakukan pada panjang gelombang $254 \mathrm{~nm}$ yang ditujukan untuk mengetahui kemiripan senyawa yang dihasilkan oleh tanaman induk dan kultur pucuk Dendrobium anosmum-gigantea. Kemiripan kedua sampel ditunjukkan dari hasil spektra

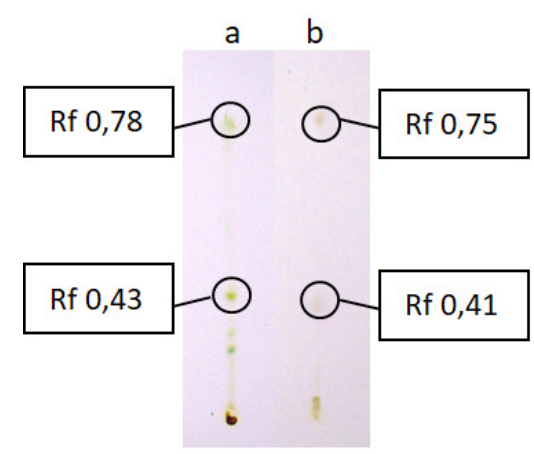

1

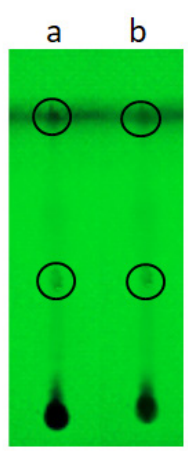

2

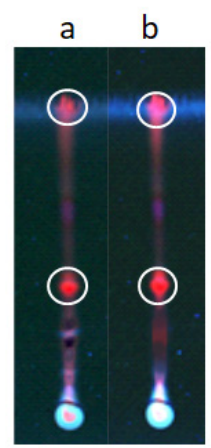

3

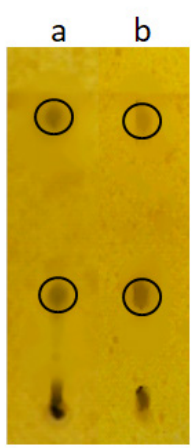

4

Gambar 3. Hasil identifikasi KLT ekstrak tanaman induk dan kultur pucuk Dendrobium anosmum-gigantea, (a) tanaman induk; (b) kultur pucuk; (1) Sinar tampak; (2) UV 254 nm; (3) UV 366 nm; (4) Penampak noda Dragendorf
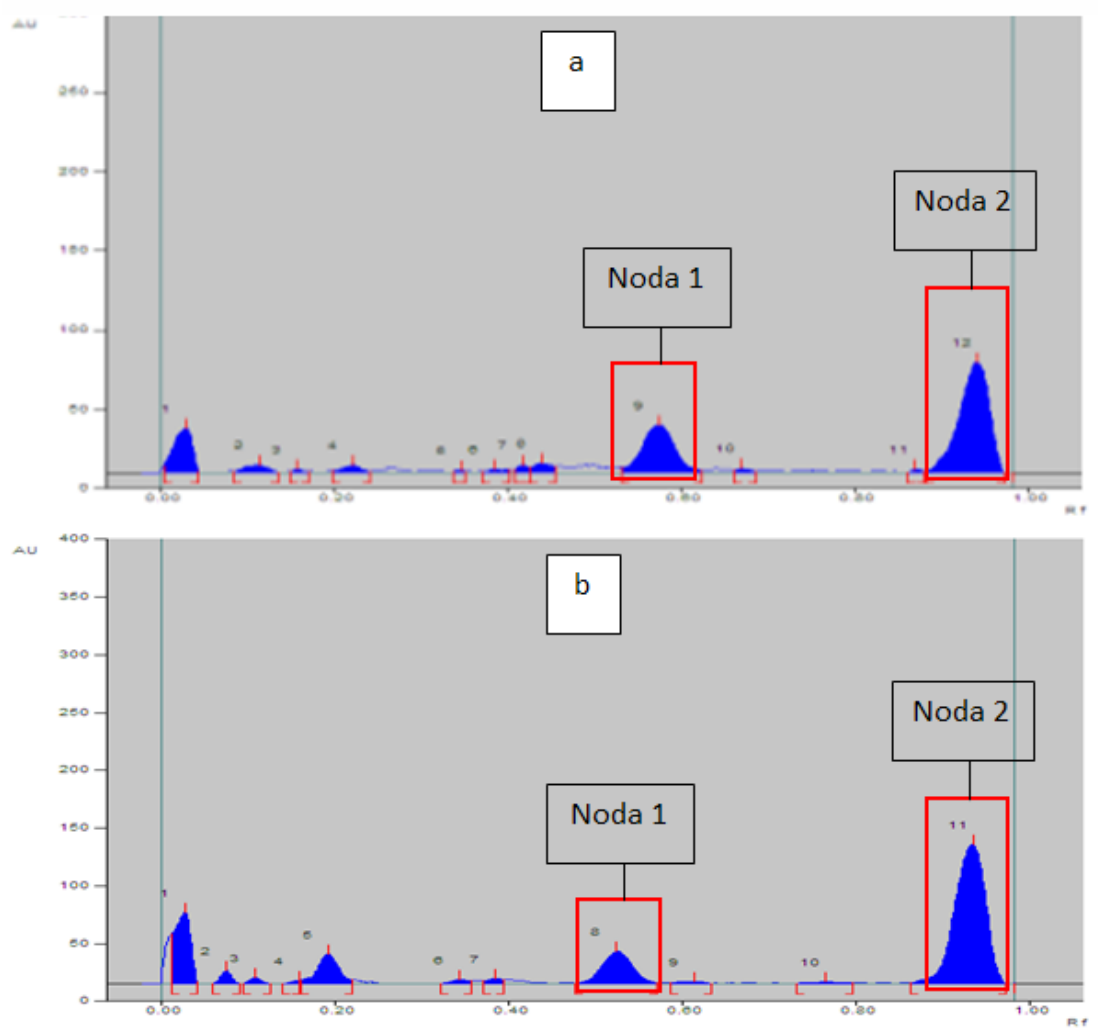

Gambar 4. Hasil identifikasi densitometri ekstrak tanaman induk dan kultur pucuk Dendrobium anosmum-gigantea, (a) tanaman induk; (b) kultur pucuk 
densitogram yang muncul pada Rf 0,50-0,60 dan 0,90-1,00. Densitogram dapat dilihat pada Gambar 4.

Dari hasil skrining fitokimia menggunakan spot test dan KLT, didapatkan beberapa golongan senyawa yang kemungkinan terdapat pada tanaman induk dan kultur pucuk Dendrobium anosmum-gigantea yaitu alkaloid, flavonoid, tanin, dan fenol. Hasil penelitian ini sama dengan hasil pada penelitian sebelumnya yang menyebutkan bahwa spesies Dendrobium memiliki kandungan golongan senyawa alkaloid yang di dalamnya terkandung senyawa aktif utama yang memiliki aktifitas farmakologi yaitu dendrobine $\left(\mathrm{C}_{16} \mathrm{H}_{25} \mathrm{O}_{2} \mathrm{~N}\right)$ [2]. Penelitian yang lain menyebutkan spesies ini juga memiliki golongan senyawa polifenol antara lain flavonoid, fenol, dan tanin [16]. Kemiripan kandungan senyawa yang dilihat dari hasil skrining fitokimia maupun hasil densitometri, menunjjukan bahwa kultur pucuk Dendrobium anosmum-gigantea dapat menghasilkan metabolit yang serupa dengan tanaman induk. Pada spesies Dendrobium tertentu, metabolit sekunder yang dihasilkan oleh kultur lebih banyak dari pada tanaman induk, hal tersebut disebabkan karena adanya kondisi stres pada lingkungan [17].

Oleh sebab itu, perbanyakan melalui kultur jaringan tanaman dapat dilakukan tanpa merubah produk metabolit dari tanaman induk. Selain itu, dengan menggunakan kultur jaringan tanaman dapat menghasilkan klon secara cepat, tanpa dipengaruhi cuaca dan letak geografis, terutama untuk tanaman yang memerlukan kondisi khusus atau sulit diperbanyak dengan menggunakan cara vegetatif konvensional, seperti spesies anggrek [7].

\section{Kesimpulan}

Berdasarkan hasil skrining fitokimia, analisis KLT dan densitometri, kultur pucuk Dendrobium anosmum-gigantea mempunyai kemiripan dengan tanaman induk jika dilihat dari kandungan golongan senyawa, sehingga kultur pucuk bisa digunakan sebagai alternatif untuk produksi golongan senyawa metabolit yang sama pada tanaman anggrek Dendrobium anosmum-gigantea. Oleh karena itu, perlu penelitian lebih lanjut untuk mengoptimalkan produksi golongan senyawa pada kultur pucuk agar kuantitasnya sama atau lebih banyak dari pada tanaman induk, salah satunya dengan cara meningkatkan jumlah biomasa dari kultur dan optimalisasi kondisi lingkungan kultur.

\section{Daftar Pustaka}

1. Andiani Y. Usaha Pembibitan Anggrek Dalam Botol. Yogyakarta: Pustaka Baru Press; 2008.

2. Bulpitt CJ, Li Y, Bulpitt PF, Wang J. The use of orchids in Chinese medicine. Journal of the Royal Society of Medicine. 2007;100(12):558-63.

3. Agromedia. Memanfaatkan Pekarangan untuk Taman Obat Keluarga. Jakarta Selatan: PT. Agromedia Pustaka; 2007.

4. Paudel MR, Rajbanshi N, Sah AK, Acharya A, Pant B. Antibacterial activity of selected Dendrobium species against clinically isolated multiple drug resistant bacteria. African Journal of Microbiology Research. 2018;12(18):426-32.

5. Ng TB, Liu J, Wong HJ, Ye X, Sze SCW, Tong Y, Zhang KY. Review of research on Dendrobium, a prized folk medicine. Appl Microbiol Biotechnol. 2012;93(5):1795-803.

6. Yunita O. Karakterisasi Profil Metabolit dan Uji Toksisitas In Vitro Ekstrak Daun Katuk (Sauropus androgynus), sebagai Upaya Pengujian Keamanan Suplemen Herbal. Surabaya: Disertasi Program Pascasarjana Universitas Airlangga; 2011.

7. Zulkarnain. Kultur Jaringan Tanaman. Jakarta: Bumi Aksara; 2009.

8. Rolandini A. Optimasi Media Pertumbuhan Kultur Pucuk Dendrobium anosmum-gigantea. Surabaya: Skripsi Farmasi Universitas Surabaya; 2017.

9. Chen ND, Gao F, Lin X, Jin H. Comparative study on alkaloids of tissue-culture seeding and wild plant 
of Dendrobium huoshanense. Journal of Chinese medicinal materials. 2014;37(6):953-6.

10. Cootes J. The Smell of Summer - Dendrobium anosmum. Manilla Bulletin. The Irish Orchid Society. 2016;14(2):24-5.

11. Gogoi M, dan Basumatary M. Estimation of the chlorophyll concentration in seven Citrus species of Kokrajhar district, BTAD, Assam, India. Tropical Plant Research. 2018;5(1):83-7.

12. Kindscher K, Cao CM, Gallagher RJ, Zhang H, Long Q, Service L, Martin LM, Timmermann BN. Comparison of Bioactive Secondary Metabolites in Experimental and Natural Populations of Wild Tomatillos, Physalis longifolia Nutt. A Journal of Plants, People, and Applied Research. 2014;12:175-82.

13. Subramaniam S, Sundarasekar J, Sahgal G, Murugaiyah V. Comparative Analysis of Lycorine in Wild Plant and Callus Culture Samples of Hymenocallis littoralis by HPLC-UV Method. The
Scientific World Journal. 2014;2014:1-6.

14. Yang D, Cheng ZQ Yang L, Hou B, Yang J, Li XN, Zi CT, Dong FW, Liu ZH, Zhou J, Ding ZT, Hu JM. Seco-Dendrobine-Type Alkaloids and Bioactive Phenolics from Dendrobium findlayanum. J. Nat. Prod. 2018;81(2):227-35.

15. Li R, Liu T, Liu M, Chen F, Liu S, Yang J. Antiinfluenza A Virus Activity of Dendrobine and Its Mechanism of Action. J. Agric. Food Chem. 2017;65(18):3665-7.

16. Li XW, Chen HP, He YY, Chen WL, Chen JW, Gao L, Hu HY, Wang J. Effects of Rich-Polyphenols Extract of Dendrobium loddigesii on AntiDiabetic, Anti-Inflammatory, Anti-Oxidant, and Gut Microbiota Modulation in $\mathrm{db} / \mathrm{db}$ Mice. Molecules. 2018;23(12):3245.

17. Bhattacharyya P, Kumaria S, Diengdoh R, Tandon P. Genetic stability and phytochemical analysis of the in vitro regenerated plants of Dendrobium nobile Lindl., an endangered medicinal orchid. Meta Gene 2. 2014;2:489-504. 


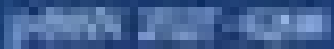

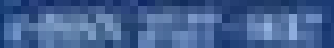

\section{促}

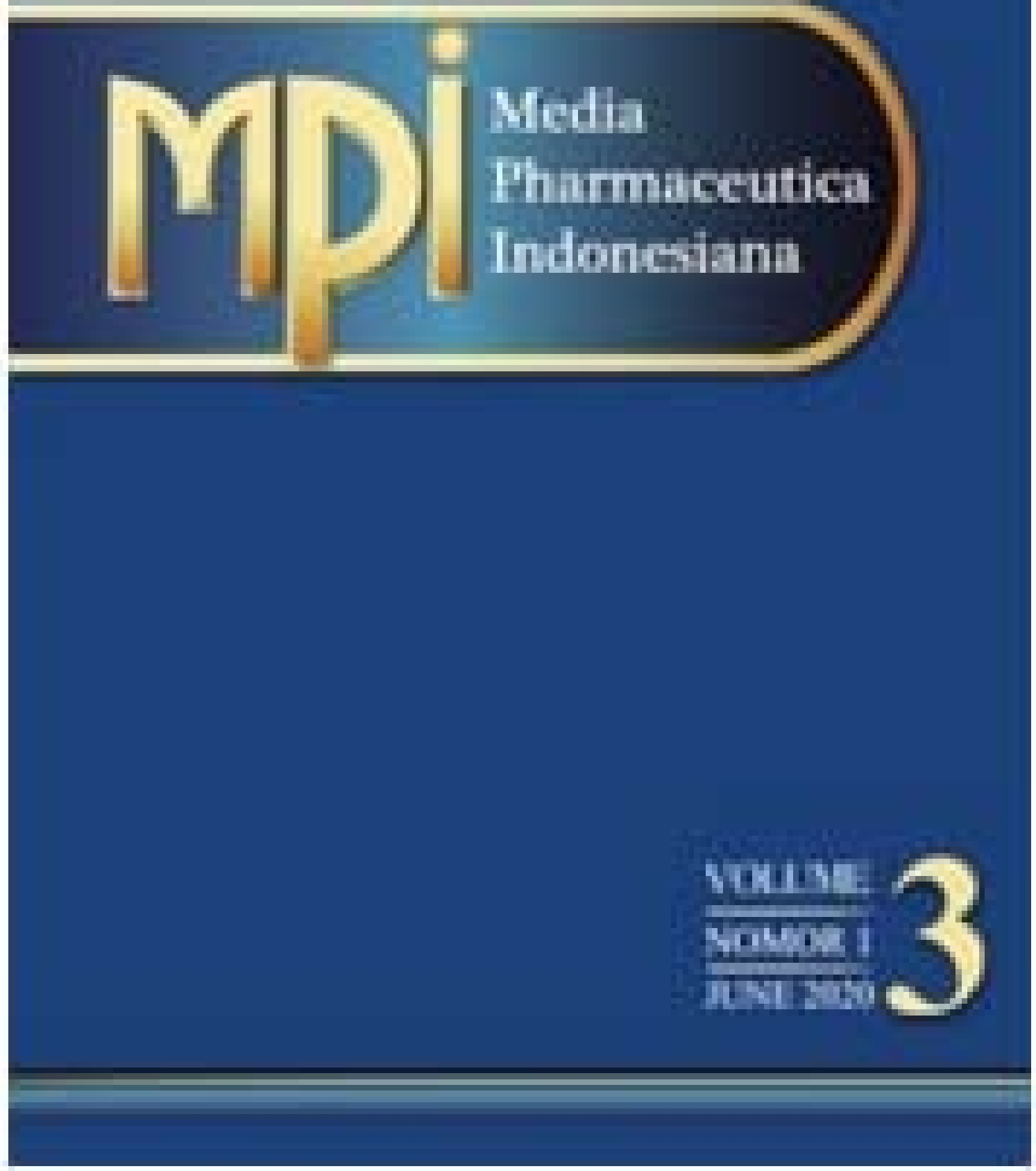


Journal Profile

\section{MPI (Media Pharmaceutica Indonesiana)}

eISSN : 25279017 I pISSN : 25276298

Health Science

Universitas Surabaya

\section{Cînta}

S4

Sinta Score

\section{v Paruda}

Indexed by GARUDA

7

H-Index

7

H5-Index

Citations 


\section{Editorial Team}

\section{Editor in Chief}

Kartini, S.Si., M.Si.., Apt.., Ph.D. Sinta Scopus

\section{Associate Editor}

Dr. Herman J. Woerdenbag Scopus

Assoc. Prof. Dr. Omboon Vallisuta Scopus

Dr. Menino Osbert Cotta Scopus

Dr. Christina Avanti M.Si., Apt. Sinta Scopus

Prof. Dr. Dwi Setyawan, S.Si., M.Si., Apt. Sinta Scopus

Dr. Rika Yulia, S.Si., SpFRS., Apt. Sinta Scopus

Dr. Oeke Yunita, S.Si.. M.Si.., Apt. Sinta Scopus

Rr. Retno Widyowati, S.Si., M.Pharm., Apt. Sinta) Scopus

Dr. Finna Setiawan, S.Farm.. M.Si. Sinta Scopus

Desak Ketut Ernawati. S.Si.. Apt. M.Pharm., Ph.D. Sinta Scopus

Dr. Susi Ari Kristina, M.Kes.. Apt. Sinta Scopus

Dr. Dini Kesuma, S.Si., M.Si., Apt. [Sinta) Scopus

Hendri Wasito, 5.5i., M.5c., Apt Sinta Scopus

Prof. I Ketut Adnyana, M.Si., Ph.D. Sinta Scopus

\section{Administrator}

Siti Kusnul Khotimah

Maya Harfia A., A.Md. 
Vol. 3 No. 1 (2020): JUNE

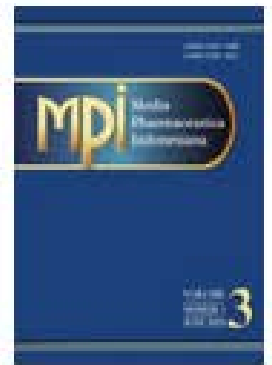

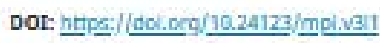

Published: 2020-06-20

Original Research Articles

Pengembangan Granul Herbal Pada Tanaman Kumis Kucing, Temulawak, dan Pegagan dengan Pengisi Maltodextrine dan Spray Dried Lactose

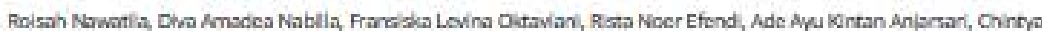

Dewe Tanuwjaya, Rahms Anicts Putr, Adrya Trias Pradans

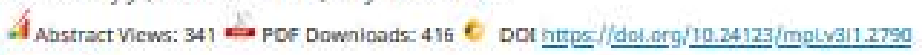

E PCF

Karakterisosi Senyawa Metabolit pada Kultur Anggrek Dendroblum anosmum.gigantea

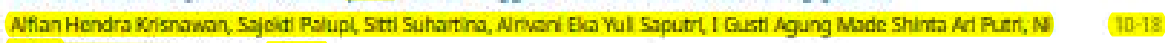
Made Swogt Wandhin, Dolic Yunta

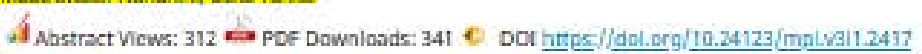

E PDF

Rhirome Buds Disinfection for Preparation of Red Ginger (Zingiber offcinale Roxb. var. rubrum Rosc.) In Vitro Culture

Popy Hartaric Hardin, Atan Hendra Krianawan

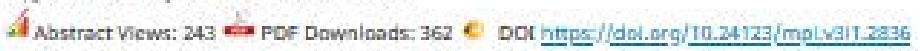

R PDF

Simultaneous HPLC Determination of Lidocsine Hydrochloride and Hexachlorophene in a Suppository Product Coce Furwert, Kunuma Hendrajsye, Qunwasn indrayanto

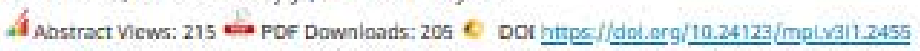

Cost Saving of Stress Ulicer Prophylaxts Used in Non-Intensive Care Unit (ICU) Inpatients Hening Fratw, Leksmi Miharant, Ika Mustikaningtias

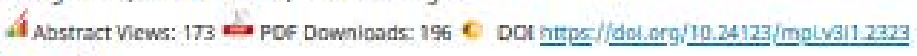

Profil Penggunaan Antibiotik. Pada Pasien Pediatri Rujukan Berdasarkan Sistem Defined Dally Dose (OOD) Nurul Fatmowati Pu Upa, Widyazi Widaty, Frans O.H. Prasesyadi

4 Abstract Vicws: 251 PDF Downlasds: 180 C Dot htege//dol.gerg/10.24123/maLl.v311.2503

Q POF

Efektiwitas Protilaksis Primer Fllgrastim Pada Pasien Kanker Payudara terhadap Insiden Neutropenia Andr Utomo, widyoe Wdyati, Dw Har Siald

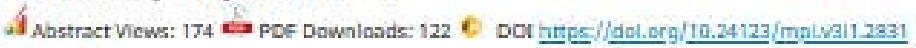

